\title{
HUBUNGAN ANTARA RESPON KOPING DENGAN KECEMASAN MAHASISWA S1 KEPERAWATAN SAAT PERTAMA KALI PRAKTIK DIRUMAH SAKIT
}

\author{
Dwi Heppy Rochmawati ${ }^{1}$, Nawangsari Wahyuningtyas Abdussamad ${ }^{2}$ \\ ${ }^{1}$ Dosen Keperawatan Jiwa Fakultas Ilmu Keperawatan, Universitas Islam Sultan Agung semarang \\ ${ }^{2}$ Mahasiswa Prodi S1 Keperawatan Fakultas Ilmu Keperawatan, Universitas Islam Sultan Agung semarang \\ dwiheppy@unissula.ac.id
}

\begin{abstract}
ABSTRAK
Praktek klinik memberikan pengalaman belajar kepada mahasiswa dalam mencapai keberhasilan dalam proses pendidikan. Pengalaman klinik yang pertama kali merupakan pengalaman yang paling menyebabkan cemas. Tujuan penelitian ini untuk mengetahui hubungan antara respon koping dengan kecemasan mahasiswa S1 keperawatan pada saat pertama kali praktik dirumah sakit. Penelitian ini merupakan penelitian kuantitatif non eksperimental dengan studi korelasi. Jumlah responden sebanyak 64 orang dengan teknik purposive sampling. Berdasarkan hasil analisa diperoleh bahwa dari sebagian besar responden memiliki berumur 18-19 tahun sebanyak 89,10\% dan berjenis kelamin yaitu sebagian besar memiliki jenis kelamin perempuan sebanyak 89.10\%. Hasil menunjukan bahwa 51,6 \% responden mempunyai respon koping maladaptif dan $60.9 \%$ responden mempunyai cemas sedang. Tidak ada hubungan antara respon koping dengan kecemasan mahasiswa S1 keperawatan pertama saat kali praktik di rumah sakit $p$ value $0,081(>0,05)$
\end{abstract}

Kata kunci : Kecemasan, Non eksperimental, Purposive sampling

\section{RELATIONSHIP BETWEEN THE RESPONSE WITH THE ANXIETY OF NURSING S1 STUDENTS AT THE FIRST TIME OF HOSPITAL PRACTICES}

\begin{abstract}
Clinical practice provides learning experiences to students in achieving success in the education process. The first clinical experience was the most worrying experience. The purpose of this study was to determine the relationship between coping responses and the anxiety of nursing undergraduate students at the time of their first practice in the hospital. This research is a non-experimental quantitative study with correlation studies. The number of respondents was 64 people with a purposive sampling technique. Based on the results of the analysis, it was found that from the majority of respondents having an age of 18-19 years as many as $89.10 \%$ and having sex, most of them had female sex as much as $89.10 \%$. The results showed that $51.6 \%$ of respondents had maladaptive coping responses and $60.9 \%$ of respondents had moderate anxiety. There is no relationship between coping responses and the anxiety of the first nursing S1 students when they practice at the hospital $p$ value $0.081(>0.05)$
\end{abstract}

Keywords: Anxiety, Non-experimental, Purposive sampling

\section{PENDAHULUAN}

Keperawatan merupakan suatu bentuk pelayanan profesional yang merupakan bagian integral dari pelayanan biopsikososial dan spiritual dan komperhensif, ditujukan kepada individu, keluarga, masyarakat baik sakit maupun sehat yang mencakup seluruh proses kesehatan pada manusia (Nursalam, 2007). Untuk memperuleh tenaga keperawatan diperlukan proses pembelajaran baik diinstitusi pendidikan maupun pengalaman belajar klinik dirumah sakit. Mahasiswa perawat harus melewati tahapan pendidikan akademik secara teori serta memenuhi tuntutan praktikum untuk mengembangkan keterampilan teorI. Hal ini didapatkan terutama ketika praktek di rumah sakit dan klinik. Pendidikan klinik adalah bagian dasar dari kurikulum keperawatan. Selain itu, praktek klinik juga merupakan kinerja dari pelayanan kesehatan, penerapan pengetahuan dan keterampilan keperawatan dasar. Kinerja pelayanan kesehatan tersebut meliputi: meningkatkan, mempertahankan kesehatan publik, mengajarkan teori atau praktik dan melakukan tindakan keperawatan dasar seperti melakukan pengkajian keperawatan (biodata klien, keluhan utama, mengukur tanda-tanda vital, pemeriksaan fisik, 
dll) serta menentukan diagnosa keperawatan. Praktek klinik memberikan pengalaman belajar kepada mahasiswa dalam mencapai keberhasilan dalam proses pendidikan. Penelitian Hart dan Rotem dalam Syarif,dkk (2005) menunjukkan bahwa pengalaman klinik yang pertama kali merupakan pengalaman yang paling menyebabkan cemas.

Kecemasan adalah kekuatiran yang tidak jelas dan menyebar, berkaitan dengan perasaan tidak pasti dan tidak berdaya. Keadaan emosi ini tidak memiliki objek yang spesifik ansietas berbeda dengan rasa takut yang merupakan penilaian intelektual terhadap bahaya. Ansietas adalah respon emosional terhadap penilaian tersebut. Kecemasan diidentifikasikan menjadi 4 tingkat yaitu ringan, sedang, berat dan panik(Stuart, G,W. 2006).

Penelitian Hart dan Rotem dalam Syarif, dkk (2005) Munculnya kecemasan pada diri mahasiswa akan mempengaruhi kualitas pembelajaran mahasiswa dalam lingkungan klinik dimana kecemasan akibat lingkungan baru dan perasaan tidak mampu/ tidak berkompeten menghadapi situasi klinik akan menyebabkan mahasiswa tidak mampu berperan aktif dalam pembelajaran klinik, takut untuk melakukan sesuatu, menurunkan kemampuan berfikir kritis dan bahkan menyebabkan penurunan kemampuan untuk menerima dan mengolah informasi dengan baik.

Mahasiswa yang akan melakukan praktik untuk pertama kali memikirkan situasi baru dan tugas tugas praktik apa yang akan mereka hadapi nanti. Mahasiswa yang pertama kaliakan memasuki praktik klinik di rumah sakit, karena sebelumnya mereka belum pernah mengalaminya langsung, dan rasa takut itu pasti ada. Sebelumnya, tetapi mahasiswa masih merasa cemas untuk menghadapi praktik langsung di lahan, karena akan berhadapan langsung dengan manusia atau pasien yang nyata, berbeda ketika waktu di kampus yang sebagian besar pasiennya dari alat peraga atau bisa juga di sebut dalam bahasa kesehatan yaitu probandus/ manekim. Kecemasan ini sangat berpengaruh terhadap mahasiswa pada praktik klinik karena mahasiswa akan melakukan pengkajian keperawatan serta penentuan diagnosa keperawatan pada pasien untuk pertama kali sehingga apa bila kecemasannya tidak di minimalkan maka sangat berpengaruh terhadap hasil dari pengkajian dan diagnosa yang mahasiswa peroleh.

Faktor-faktor yang dapat menyebabkan individu mengalami kecemasan adalah keadaan biologis, kemampuan beradaptasi/ mempertahankan diri terhadap lingkungan yang diperoleh dari perkembangan dan pengalaman, serta adaptasi terhadap rangsangan, situasi atau stressor yang dihadapi. Sumber stressor/ situasi yang dapat menyebabkan kecemasan didapatkan dari lingkungan sosial. Lingkungan sosial mempunyai aturan-aturan, kebiasaan, hukumhukum yang berlaku di daerah tertentu. Hal inilah yang menyebabkan individu harus dapat menyesuaikan diri dengan lingkungan sosial yang ada.Individu yang tidak dapat menyesuikan diri dengan norma/aturan dalam masyarakat akan menyebabkan ketidakseimbangan dalam diri dan sosialnya, sehingga dapat menimbulkan kecemasn (Simandjuntak, dkk, 1984 dalam Pratiwi,Ratih Putri, 2010). Berdasarkan uraian dari latar belakang di atas maka penulis tertarik untuk meneliti hubungan antara respon koping dengan kecemasan mahasiswa S1 keperawatan saat pertama kali praktik dirumah sakit .

\section{METODE}

Penelitian ini merupakan penelitian kuantitatif non eksperimental yang menggambarkan hubungan antara respon koping dengan kecemasan mahasiswa S1 keperawatan pada saat pertama kali praktik di Rumah Sakit. Metode penelitian yang digunakan cross sectional. Penelitian ini menggunakan Purposive Sampling dengan menggunakan Rumus perhitungan dari Notoatmodjo (2010) maka didapatkan Jumlah sampel sebanyak 64 orang Penelitian dilakukan di Fakultas Ilmu keperawatan Universitas Islam Sultan Agung Semarang pada tanggal 29 februari 2016 sampai dengan tanggal 4 maret 2016.

\section{HASIL}

Distribusi frekuensi responden berdasarkan umur dan jenis kelamin dengan jumlah sampel 64 orang sebagai berikut : 
Tabel 1

Distribusi frekuensi responden berdasarkan umur $(\mathrm{n}=64)$

\begin{tabular}{|c|c|c|}
\hline Umur & $\mathrm{f}$ & $\%$ \\
\hline 18 tahun & 6 & 9.4 \\
\hline 19 tahun & 51 & 79.7 \\
\hline 20 tahun & 7 & 10,90 \\
\hline
\end{tabular}

Tabel 2

Distribusi frekuensi Responden Penelitian berdasarkan jenis kelamin ( $\mathrm{n}=64)$

\begin{tabular}{lcc}
\hline \multicolumn{1}{c}{ Jenis Kelamin } & $\mathrm{f}$ & $\%$ \\
\hline Perempuan & 57 & 89,1 \\
Laki-laki & 7 & 10,9 \\
\hline
\end{tabular}

Tabel 3

Distribusi frekuensi Responden Penelitian berdasarkan Respon Koping(n=64)

\begin{tabular}{lcc}
\hline \multicolumn{1}{c}{ Respon koping } & $\mathrm{f}$ & $\%$ \\
\hline Maladaptif & 33 & 51,6 \\
Adaptif & 31 & 48,4 \\
\hline
\end{tabular}

Tabel 4

Distribusi frekuensi responden berdasarkan Kecemasan ( $\mathrm{n}=64)$

\begin{tabular}{lcc}
\hline \multicolumn{1}{c}{ Kecemasan } & Frekuensi & Persentase $(\%)$ \\
\hline Tidak ada & 6 & 9,4 \\
Cemas ringan & 13 & 20,3 \\
Cemas sedang & 39 & 60,9 \\
Cemas berat & 6 & 9,4 \\
\hline
\end{tabular}

Tabel 5

Hubungan Variabel Bebas dengan Variabel Terikat

\begin{tabular}{ccccccccc}
\hline Respon koping & \multicolumn{2}{c}{ Kecemasan mahasiswa saat pertama kali praktik } & & & \\
& $\begin{array}{c}\text { Tidak } \\
\text { cemas }\end{array}$ & $\begin{array}{c}\text { Cemas } \\
\text { ringan }\end{array}$ & $\begin{array}{c}\text { Cemas } \\
\text { sedang }\end{array}$ & $\begin{array}{c}\text { Cemas } \\
\text { berat }\end{array}$ & Total & $r$ & $P$ \\
\hline Mal adaptif & 4 & 7 & 22 & 0 & 33 & 0.36 & 0.08 \\
adaptif & 2 & 6 & 17 & 6 & 31 & 6 & 1 \\
\hline
\end{tabular}

\section{PEMBAHASAN}

Dari hasil uji korelatif Gamma untuk pengujian hipotesis penelitian dapat diketahui nilai sig. 0,081>0,05 yang artinya Ho diterima, dan Ha ditolak. Artinya tidak ada hubungan yang signifikan antara respon koping dengan kecemasan mahasiswa S1keperawatan saat pertama kali praktikdi rumah sakit.

Respon seseorang terhadap stres dan kecemasan bergantung, tetapi terbatas padafaktor-faktor berikut ini yaitu usia, maturasi perkembangan, status kesehatan jiwadan fisik, predisposisi genetik, nilai-nilai budaya dan spiritual, dukungan sosialdan lingkungan, dan respon koping yang dipelajari (Isaacs, 2004).

Responden yang merupakan mahasiswa dalam golongan dewasa awal (muda) sedang mengalami permasalahan transisi dan perubahan, baik yang bersifat positif maupun negatif dapat menjadi penyebab stres. Stres dan kecemasan dapat memotivasi dan menantang seseorang, sekaligus menyebabkan distres. Kecemasan tumbuhsemakin kuat sehingga dapat mempengaruhi kemampuan fungsional individu.Kesulitan-kesulitan saat klinik pertama oleh mahasiswa sering dirasakan sebagai suatu beban yang berat, akibatnya kesulitan-kesulitan yang dirasakan tersebut berkembang menjadi sikap yang 
negatif yang akhirnya dapat menimbulkan suatu kecemasan dan hilangnya motivasi.

\section{SIMPULAN DAN SARAN}

\section{Simpulan}

Karakteristik responden mahasiswa S1 keperawatan Prodi S1 keperawatan Universitas Islam Sultan Agung Semarang yang melaksanakan praktik pertama kali dirumah sakit berdasarkan umur yaitu sebagian besar berusia $18-19$ tahun $(89,1 \%)$, berjenis kelamin perempuan $(89,1 \%)$ serta tingkat kecemasan sedang sebanyak 60,9\%. Variabel Respon koping tidak ada hubungan dengan kecemasan mahasiswa S1 keperawatan saat pertama kali praktik dirumah sakit karena $p$ value $>0.05$ dengan keeratan hubungan sedang $(r=0.366)$.

\section{Saran}

Hasil dari penelitian salah satu acuan dan pertimbangan yang dapat digunakan oleh peneliti lainnya. Bagi peneliti selanjutnya dapat menggunakan variabel lain misalnya metode pembelajaran oleh instruktur klinik, media pembelajaran klinik, fasilitas ruang/klinik, dan sebagainya sehingga hasil penelitian ini menjadi lebih objektif, dan lengkap

\section{DAFTAR PUSTAKA}

Locken, T., \& Norberg, H. (2007). Reduced anxiety improves learning ability of nursing students through utilization of mentoring triads. Retrieved from http://tinyurl.com/27pz979

Notoatmodjo, S.(2010).Ilmu Perilaku Kesehatan. Rineka Cipta. Jakarta

Nursalam. (2007). Manajemen Keperawatan aplikasi dalam praktik keperawatan professional edisi 2 .Salemba medika.Jakarta

Pratiwi, R. P .(2010). Pengertian Kecemasan. (http://psikologi.or.id diakses 28 oktober 2015)

Stuart, G,W. (2006).Buku saku keperawatan Jiwa Edisi 5, EGC.Jakarta

Syarif, dkk. (2005). A Qualitative Study of Nursing Students Experience on clinical practice (www.Biomedcentral.com diakses tanggal 28 oktober 2015)

Tomb,D.A. (2004). Buku Psikiatri edisi 6. EGC . Jakarta

Wijayanti, I.( 2012). Respon Psikososial Pada Mahasiswa S1 Keperawatan yang Sedang Menyusun Skripsi di Universitas Muhammadiyah Semarang oleh Pengaruh Tingkat Kecemasan. Semarang : Unimus 